\title{
HIDROLISIS Eucheuma cottonii DENGAN ENZIM K-KARAGENASE DALAM MENGHASILKAN GULA REDUKSI UNTUK PRODUKSI BIOETANOL
}

\section{HIDROLISYS OF Eucheuma cottonii BY K-CARRAGENASSE IN PRODUCE REDUCING SUGAR TO PRODUCTION OF BIOETHANOL}

\author{
Mustika Zelvi $^{1)^{*}}$, Ani Suryani' ${ }^{2)}$, dan Dwi Setyaningsih ${ }^{2)}$ \\ Departemen Teknologi Industri Pertanian, Fakultas Teknologi Pertanian, Institut Pertanian Bogor, \\ Kampus IPB Darmaga, Jl. Raya Dramaga, Bogor, Indonesia \\ E-mail:m4zelv1@gmail.com
}

Makalah: Diterima 27 Juli 2016; Diperbaiki 12 Juni 2017; Disetujui 20 Juni 2017

\begin{abstract}
Bioethanol is one of the renewable resources derived from sugar fermentation process of carbohydrate substance with microorganismaid. Hydrolysis is the stage to get the simple sugar and is done with using $k$ carragenasethat is obtained from the isolation result of marine microbe in E.cottonii's habitat. The objectives of this research were to gain time hydrolysis to produce the enzyme activity and reducing sugar highs by $k$ karagenase and to determine the best of the substrate concentration and k-carragenasein producing a reduction sugar and the highest ethanol. The research steps was started from isolate rejuvenation of IH22 microbe, enzyme production of crudeextraction $k$-carragenase and $80 \%$ acetone precipitation, determination of the hydrolysis timeand activity of $k$-carragenase. The next step was the substrate hydrolysis with amounts of 6\%, $9 \%$, and $12 \%$ $(\mathrm{b} / \mathrm{v})$ solids, by enzyme from acetone concentrations of $0 \%, 2.5 \%$, and $5 \%(\mathrm{v} / \mathrm{v})$ and then they were fermented for six days with the S.cereviseaeadapted yeast extract. Thek-carragenasse highest enzyme activity was obtained in incubation for 30-60 minutes while the highest reduction sugar was obtained inhydrolysis time for 120 minutes. During the hydrolysis, $12 \%$ substrate concentration generated the highest reduction sugar and whole sugar of $3.21 \%$ and $9.89 \%$, respectively, while $9 \%$ substrate with $5 \%$ enzyme treatment contained $1.49 \%$ reduction sugar and $2.75 \%$ whole sugar, which was the best substrate in producing ethanol during fermentation process of $1.23 \%(\mathrm{v} / \mathrm{v})$ and $0.82 \%(\mathrm{~b} / \mathrm{v})$ with $55.78 \%$ substrate efficiency and $70.44 \%$ fermentation efficieny.
\end{abstract}

Keywords : bioethanol, Eucheuma cottonii, $k$-carragenasse, S.cerevisiae

\section{ABSTRAK}

Bioetanol merupakan salah satu sumber bahan bakar terbarukan yang diperoleh dari proses fermentasi gula dari bahan berkarbohidrat dengan bantuan mikroorganisme. Hidrolisis adalah tahapan untuk mendapatkan gula sederhana dari rumput laut dengan menggunakan enzim $k$-karagenase yang diperoleh dari hasil isolasi mikroba laut pada habitat Eucheuma cottonii. Tujuan penelitian ini adalah untuk mendapatkan waktu hidrolisis dalam menghasilkan aktivitas enzim dan gula reduksi tertinggi oleh $k$-karagenase dan menentukan konsentrasi substrat dan enzim terbaik dalam menghasilkan gula reduksi dan etanol tertinggi. Tahapan penelitian dimulai dari peremajaan isolatIH22, produksi enzim $k$-karagenase ekstrak kasar dan pengendapan aseton $80 \%$, penentuan waktu hidrolisis dan aktivitas enzim karagenase. Selanjutnya proses hidrolisis substratE.cottoniidengan total padatan $6 \%, 9 \%$, dan $12 \%(\mathrm{~b} / \mathrm{v})$ dengan enzim padakonsentrasi $0 \%, 2,5 \%$, dan $5 \%(\mathrm{v} / \mathrm{v})$, yangkemudian difermentasi selama 6 hari dengan bantuan khamirteradaptasi S.cereviseae. Aktivitas enzim $k$-karagenase tertinggi diperoleh pada waktu inkubasi 30-60 menitdan gula reduksi tertinggi diperoleh setelah inkubasi selama 120 menit. Selama proses hidrolisis, konsentrasi substrat $12 \%$ menghasilkan gula reduksi dan total gula tertinggi sebesar 3,21\% dan 9,89\%,sedangkan substrat $9 \%$ dengan perlakuan enzim 5\% yang mengandung gula reduksi $1,49 \%$ dan total gula $2,75 \%$, merupakan substrat terbaik dalam menghasilkan etanol selama proses fermentasi, yaitu $1,23 \%$ (v/v) dan $0,82 \%$ (b/v) dengan efisiensi substrat55,78\% dan efisiensi fermentasi 70,44\%.

Kata kunci: bioetanol, Eucheuma cottonii, $k$-karagenase,S.cerevisiae

\section{PENDAHULUAN}

Salah satu sumber bahan bakar terbarukan dan ramah lingkungan yang sangat prospektif saat ini adalah bioetanol. Penggunaan bioetanol sangat dibutuhkan untuk 10 tahun kedepan, dimana berdasarkan peraturan Kementrian Energi dan Sumber Daya Mineral No.32 tahun 2008, pada tahun 2008 hingga 2010 etanol harus mensubstitusi premium sebanyak 3\% untuk transportasi, meningkat menjadi $10 \%$ pada tahun 2010 dan akan meningkat $15 \%$ di tahun 2025 (Sutarto, 2009). Bioetanol diperoleh dari proses fermentasi gula bahan-bahan berkarbohidrat menggunakan bantuan mikroorganisme.

Bioetanol dapat dibuat dari bahan baku tanaman yang kaya akan pati, serat dan gula. Salah satu bahan yang potensial yaitu rumput laut.Jenis 
rumput laut yang paling banyak digunakan adalah Eucheuma cottonii karena jenis rumput laut ini banyak tumbuh di perairan Indonesia dengan kepadatan populasi yang tinggi. Pada rumput laut terdapat karbohidrat karagenan yang dapat digunakan sebagai bahan baku etanol (Banati et al, 2009). Kappaphycus sp atau lebih dikenal dengan Eucheuma cottonii adalah salah satu rumput laut yang menghasilkan ekstrak karagenan yang tinggi, dimana menurut Istini et al. (1986), kandungan karagenan pada rumput laut E.cottoniiadalah sebesar $65,75 \%$.

Proses pembuatan etanol dengan bahan berselulosa memerlukan beberapa tahapan sebelum menghasilkan etanol, salah satu tahapnya adalah hidrolisis. Proses hidrolisis dilakukan dengan tujuan untuk mendapatkan gula sederhana dan mempermudah kerja dalam proses fermentasi. Proses hidrolisis karagenan yang merupkan polimer galaktosa terdapat dalam Eucheuma cottonii dapat dilakukan dengan dua cara, yaitu secara kimiawi dan enzimatik. Menurut Riyanti (2008) efisiensi proses hidrolisis dengan menggunakan asam masih rendah serta penanganan limbah asam yang tidak mudah. Kelemahan lainnya adalah menghasilkan senyawa toksik yang dapat menghambat pertumbuhan mikroorganisme pada proses fermentasi nantinya. Sehingga banyak yang beralih menggunakan hidrolisis enzimatik dimana selain produk yang dihasilkan aman, senyawa penghambat pertumbuhan mikroba tidak terbentuk.

Enzim $k$-karagenase merupakan enzim yang memiliki aktivitas tinggi dalam menghidrolisis $k$ karagenan. Enzim yang digunakan adalah enzim yang diproduksi dari hasil isolasi mikroba laut pada habitat Eucheuma cottonii dan menghasilkan isolat dengan potensi aktivitas karagenase yang tinggi. Salah satunya yaitu isolat IH22. Isolat IH22 adalah isolat mikroba laut yang berhasil diisolasi oleh laboratorium Surfactan Bioenergy Reserach Center (SBRC), LPPM IPB, dan merupakan isolat terbaik dengan nilai aktivitas tertinggi sebesar $0,061 \mathrm{IU} / \mathrm{mL}$, kadar gula reduksi yang dihasilkan sebesar 0,117 $\mathrm{mg} / \mathrm{mL}$ dengan kadar etanol yang tertinggiyaitu $0,89 \%(\mathrm{v} / \mathrm{v})$ dengan waktu inkubasi 10 jam pada suhu $40^{\circ} \mathrm{C}$. Enzim yang dihasilkan telah dievaluasi aktivitasnya dengan cara pemekatan enzim melalui pengendapan dengan aseton $80 \%$ (Meliawati, 2015). Khamir yang digunakan untuk fermentasi etanol pada penelitian ini adalah khamir S.cerevisiae yang telah diadaptasi dalam media galaktosa yaitu IPBCC AL IX, dimana kebanyakan S.cerevisiaeyang digunakan memiliki kemampuan untuk memetabolisme jenis gula tertentu salah satunya glukosa, sehingga perlu dilakukan adaptasi khamir pada media yang sesuai.

Penggunaan dan pemanfaatan enzim karagenase hasil isolasi dari lingkungan hidup rumput laut pada hidrolisis enzim $k$-karagenase merupakan penelitian yang perlu dikembangkan lagi. Hal inilah yang melatarbelakangi penelitian hidrolisis rumput laut E.cottonii dengan enzim $k$ karagenase untuk memproduksi bioetanol oleh S.cerevisiae. Penelitian ini secara umum bertujuan untuk menganalisis konsentrasi substrat E.cottonii dan enzim $k$-karagenase yang terbaik dalam menghasilkan gula reduksi selama proses hidrolisis dengan kadar etanol tertinggi pada proses fermentasi. Sebelumnya dilakukan hidrolisis terhadap enzim $k$-karagenase untuk menentukan waktu optimum enzim dalam menghasilkan aktivitas enzim dan gula reduksi yang tertinggi.

\section{Bahan}

\section{BAHAN DAN METODE}

Bahan-bahan yang digunakan penelitian ini meliputi bakteri isolat IH22 dan khamir S.cerevisiae (IPBCC AL IX), rumput laut (Eucheuma cottonii), media karagenan, kappa-karagenan, $\mathrm{CaCl}_{2}, \mathrm{KCl}$, $\mathrm{MgSO}_{4}, \quad \mathrm{~K}_{2} \mathrm{HPO}_{4}, \quad \mathrm{KH}_{2} \mathrm{PO}_{4}, \mathrm{NaCl}, \quad$ pepton, galaktosa,ekstrak khamir, asam dinitrolisilat (DNS), asetat $\mathrm{pH}-5$, fosfat $\mathrm{pH}-6$, dan aseton. Alat-alat yang digunakan dalam penelitian ini meliputi laminar/transfer box, cawan petri steril, labu erlenmeyer, tabung reaksi, inkubator, sentrifus, vorteks, autoklaf, pipet mikro, timbangan analitik, viskometer, refraktrometer dan alat densitometer.

\section{Metode Penelitian}

Diagram alir penelitian pada kajian ini disajikan pada Gambar 1.

\section{Peremajaan Isolat IH22}

Peremajaan bakteri dilakukan dengan menumbuhkan isolat IH22 pada media padatkappakaragenan(media agar cawan). Isolat IH22 merupakan mikroba laut yang dikoleksi oleh Laboratorium Pusat Studi Surfaktan dan Bioenergi, LPPM IPB yang diperoleh dari Perairan Desa Lontar, Serang, Banten. Selanjutnya bakteri diinkubasi selama 2 hari pada suhu $35^{\circ} \mathrm{C}$.

\section{Produksi Enzim $k$-Karagenase (Enzim Ekstrak Kasar)}

Produksi enzim $k$-karagenase dilakukan dengan cara menginokulasi isolat IH22 yang sudah diremajakan sebanyak satu ose ke dalam media startercair (galaktosa), selanjutnya diinkubasi selama 10 jam dengan suhu $35^{\circ} \mathrm{C}$ dengan kecepatan agitasi $100 \mathrm{rpm}$. Sebanyak $50 \mathrm{~mL}$ kultur starter kemudian dimasukkan ke dalam $450 \mathrm{~mL}$ media produksikkaragenan. Media produksi enzim diinkubasi pada waterbath dengan suhu $40^{\circ} \mathrm{C}$ dengan kecepatan agitasi $100 \mathrm{rpm}$ selama 12 jam (merupakan waktu optimum berdasarkan hasil gula reduksi tertinggi terhadap aktivitas enzim tertinggi pada isolat IH22) (Meliawati, 2015). 


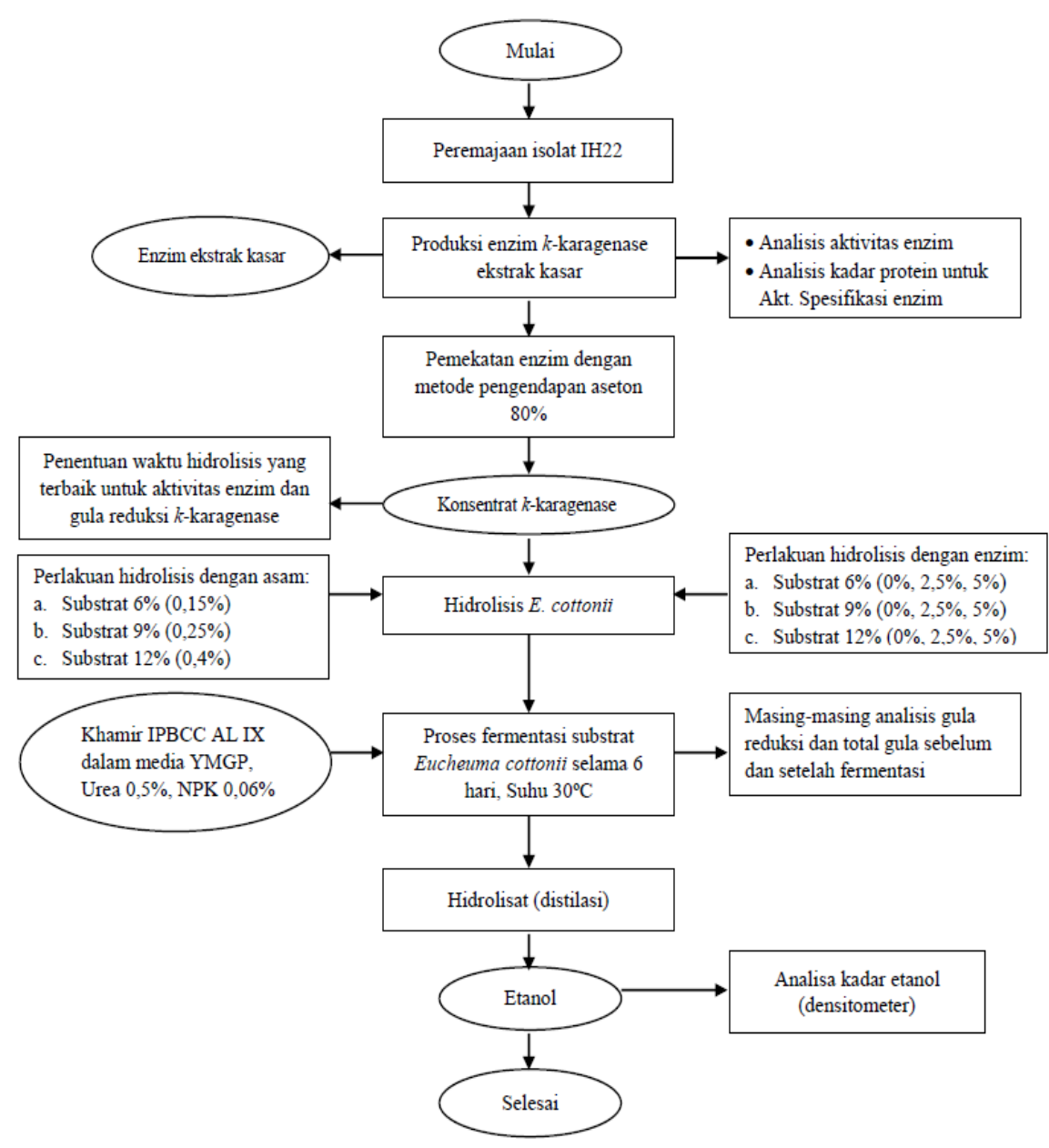

Gambar 1. Diagram alir penelitian

Langkah selanjutnya, media produksi yang mengandung enzim disentrifugasi pada kecepatan $2.500 \mathrm{rpm}$ dengan suhu $4^{\circ} \mathrm{C}$ selama 15 menit untuk memisahkan larutan enzim dengan endapan. Supernatan hasil sentrifugasi kemudian disimpan pada suhu $10^{\circ} \mathrm{C}$ sebagai enzim ekstrak kasar (Modifikasi dari Khambaty et al., 2007). Supernatan yang dihasilkan dari proses sentrifugasi enzim ekstrak kasardilakukan analisa kadar protein (metode Bradford) untuk memperoleh aktivitas spesifik enzim dengan cara pembagian nilai aktivitas enzim (IU/mL) dengan kadar proteinnya $(\mathrm{mg} / \mathrm{mL})$.

Kemudian dilakukan analisa aktivitas enzim dengan cara mengambil sampel sebanyak 0,33 $\mathrm{mL}$ supernatan ditambah $0,67 \mathrm{~mL}$ substrat karagenan dalam buffer asetat $\mathrm{pH} 5$ dan selanjutnya diaduk menggunakan vorteks dan diinkubasi selama 30 menit pada suhu $50^{\circ} \mathrm{C}$. Sebanyak $1 \mathrm{~mL}$ sampel yang telah diinkubasi ditambah dengan $3 \mathrm{~mL}$ DNS (Miller, 1959), diaduk kembali dan dipanaskan pada air yang telah mendidih selama 15 menit. Selanjutnya sampel diukur absorbansinya pada panjang gelombang $540 \mathrm{~nm}$ dan dihitung kadar gula reduksinya. Aktivitas enzim merupakan jumlah enzim yang dibutuhkan untuk menghasilkan 1 mikromol gula reduksi (D-galaktosa equivalent) permenit. Pengukuran aktivitas enzim dimasukkan ke dalam rumus dibawah ini:

Aktivitas enzim $(\mathrm{IU} / \mathrm{mL})=$

$$
\frac{\text { gula reduksi }\left(\frac{\mathrm{mg}}{\mathrm{mL}}\right) \times(\text { volume enzim }+ \text { volume substrat })}{\text { BM galaktosa } \times \text { waktu inkubasi } \times \text { volume enzim }}
$$

Keterangan:

$\mathrm{BM}$ galaktosa $=0,18 \mathrm{mg} / \mu \mathrm{mol}$

Waktu inkubasi dalam menit

Vol enzim dan vol substrat dalam $\mathrm{mL}$

\section{Pemekatan Enzim $\boldsymbol{k}$-Karagenase Ekstrak Kasar dengan Metode Pengendapan Aseton 80\%}

Enzim ekstrak kasar yang diproduksi sebanyak $500 \mathrm{~mL}$ dipekatkan dengan aseton pada konsentrasi $80 \%$ dimana sebanyak $2 \mathrm{~mL}$ enzim ekstrak kasar ditambahkan dengan pelarut aseton 8 $\mathrm{mL}$ dalam tabung reaksi. Setelah itu campuran diaduk dengan vorteks sampai homogen dan disimpan semalaman di dalam lemari pendingin. Kemudian dilakukan pemisahan dengan sentrifus selama 15 menit pada suhu $4{ }^{\circ} \mathrm{C}$. Enzim yang mengendap dipisahkan dan dilarutkan kembali ke dalam 0,05 M bufer fosfat pH 6 sebanyak $200 \mu \mathrm{L}$. Sehingga dari $500 \mathrm{~mL}$ enzim ekstrak kasar yang telah dipekatkan akan diperoleh konsnetrat enzim $k$ - 
karagenase sebanyak $50 \mathrm{~mL}$ untuk satu kali pembuatan media produksi $k$-karagenan. Kemudian enzim yang telah dimurnikan dilakukan uji aktivitas enzim dengan perhitungan yang sama dengan pengujian sebelumnya dan kadar proteinnya untuk mengetahui aktivitas spesifikasi enzim (Meliawati, 2015).

\section{Penentuan Waktu Hidrolisis terhadap Aktivitas Enzim dan Gula Reduksi Menggunakan Enzim $\boldsymbol{k}$ - Karagenase}

Pengujian dilakukan pada enzim yang telah diendapkan dengan aseton. Sebelumnya dilakukan persiapan substrat $k$-karagenan sebanyak $0,25 \%(\mathrm{w} / \mathrm{v})$ yang dilarutkan dalam bufer fosfat $\mathrm{pH}$ 6. Kemudian substrat $k$-karagenan diambil sebanyak $0,67 \mathrm{~mL}$ kemudian ditambahkan dengan konsentrat enzim $k$ karagenase sebanyak $0,33 \mathrm{~mL}$ dan dihidrolisis pada suhu $40^{\circ} \mathrm{C}$, dengan waktu pengamatan dilakukan setiap 30 menit yang dimulai dari $0,30,60,90,120$ dan 180 menit. Selanjutnya dilakukan analisa terhadap aktivitas enzim dan gula reduksi pada tiap interval 30 menit untuk memperoleh waktu inkubasi dan hidrolisis yang terbaik.

\section{Hidrolisis E.cottonii dengan Enzim $\boldsymbol{k}$-Karagenase}

Pada tahap ini, substrat yang telah dihidrolisis selama 30 menit, dinetralkan dengan kapur tohor hingga $\mathrm{pH}$ mencapai 5,5 kemudian dilanjutkan proses hidrolisis menggunakan enzim $k$ karagenase. Hidrolisat asamdengan konsentrasi $6 \%$, $9 \%$ dan $12 \%$ yang telah dingin ditambahkan enzim $k$-karagenase dengan konsentrasi $0 \%, 2,5 \%$ dan $5 \%$. Hidrolisis enzimatik dilakukan dengan cara menginkubasi substrat E.cottonii selama 2 jam(waktu hidrolisis yang terbaik untuk gula reduksi) pada suhu $40^{\circ} \mathrm{C}$, dimana banyak enzim yang ditambahkan dalam $100 \mathrm{~mL}$ bufer adalah $5 \mathrm{~mL}$ untuk konsentrasi 2,5\% dan $10 \mathrm{~mL}$ untuk konsentrasi enzim 5\% dan kemudian sisanya ditambahkan dengan bufer fosfat $\mathrm{pH} 6$ sehingga total volume hidrolisat E.cottonii yang digunakan adalah $200 \mathrm{~mL}$. Kemudian hidrolisat dipanaskan pada suhu $90^{\circ} \mathrm{C}$ selama 15 menit yang bertujuan untuk menghentikan reaksi pada hidrolisat dan masingmasing substrat diambil sampelnya untuk dianalisa gula reduksi dan total gulanya setelah hidrolisis menggunakan enzim.

\section{Fermentasi}

Substrat yang telah dihidrolisis menggunakan enzim $k$-karagenase selanjutnya difermentasi, yang sebelumnya dilakukan persiapan inokulum S.cerevisiae IPBCC AL IX yang diambil sebanyak 2 ose untuk ditanam dalam $10 \mathrm{~mL}$ media YMGP (yeast malt galactose pepton), dimana banyaknya media YMGP yang ditambahkan pada hidrolisat adalah sebesar $10 \%$ dari total volume hidrolisat yaitu sebanyak $20 \mathrm{~mL}$. Selanjutnya media diinkubasi pada suhu $30^{\circ} \mathrm{C}$ selama 24 jam
(Yanagisawa et al., 2011). Proses fermentasi dilakukan pada kondisi anaerobik pada suhu ruang $30^{\circ} \mathrm{C}$. Substrat yang telah dihidrolisis ditambahkan dengan pupuk urea $0,5 \%$ dan NPK $0,06 \%$ dari ${ }^{\circ}$ Brix gula substrat sebagai sumber nutrien (Setyaningsih et al., 2012). Proses fermentasi dilakukan selama 6 hari. Hidrolisat yang telah difermentasi diambil sampelnya untuk dilakukan analisa gula reduksi dan total gula setelah fermentasi. Selanjutnya hidrolisat hasil fermentasi didistilasi, kemudian rendemen etanol yang diperoleh diukur dengan bantuan alat densitometer $(\% \mathrm{v} / \mathrm{v})$.

\section{Pengolahan Data}

Pengolahan data dilakukan untuk mengetahui pengaruh konsentrasi substrat dan enzim terhadap proses hidrolisis dan fermentasi dilakukan uji $\mathrm{F}$ dengan RAL dua faktor. Faktor pertama yang mempengaruhi adalah konsentrasi substrat E.cottonii sebanyak 3 taraf yaitu 6\% (S1), 9\% (S2) dan 12\% (S3). Faktor kedua konsentrasi enzim dengan 3 taraf yaitu $0 \%$ (E1), 2,5\% (E2) dan 5\%(E3). Percobaan dilakukan sebanyak 2 kali dengan masing-masing pengukuran diulang sebanyak 2 kali. Apabila ada salah satu perlakuan atau interaksinya berpengaruh nyata maka analisis dilanjutkan dengan uji Duncan (Gomez dan Gomez, 1995). Parameter yang diuji diantaranya gula reduksi dan total gula selama proses hidrolisis dan fermentasi, kadar etanol, efisiensi penggunaan substrat dan efisiensi fermentasi.Persamaan model rancangannya sebagai berikut :

$$
\mathrm{Y}_{i k j}=\mu+\mathrm{S}_{i}+\mathrm{E}_{j}+(\mathrm{SE})_{i j}+\varepsilon(i j)_{k}
$$

\section{HASIL DAN PEMBAHASAN}

\section{Stabilitas Aktivitas Enzim $\boldsymbol{k}$-Karagenase pada Berbagai Waktu Inkubasi}

Pengukuran aktivitas enzim $k$-karagenase dilakukan untuk melihat berapa lama enzim dapat bekerja secara maksimal pada suhu tertentu. Satu unit aktivitas enzim didefinisikan sebagai 1 mikromol galaktosa (gula reduksi) yang dihasilkan per satuan waktu pada kondisi pengukuran enzim, yang dinyatakan dalam satuan unit/mL yang merupakan mikromol yang dilepas per menit/mL enzim.

Pada Gambar 2 terlihat bahwa aktivitas enzim mengalami peningkatan di menit 30 hingga menit ke-60 yaitu sebesar 0,007-0,01 IU/mL. Kemudian aktivitas enzim menurun di menit 120 hingga menit ke-180, dimana pada waktu ini enzim sudah kurang aktif sehingga tidak menghasilkan kenaikan gula reduksi yang tinggi. Dapat disimpulkan bahwa aktivitas enzim yang tinggi diperoleh pada awal masa inkubasi yaitu pada kisaran 30 hingga 60 menit. 


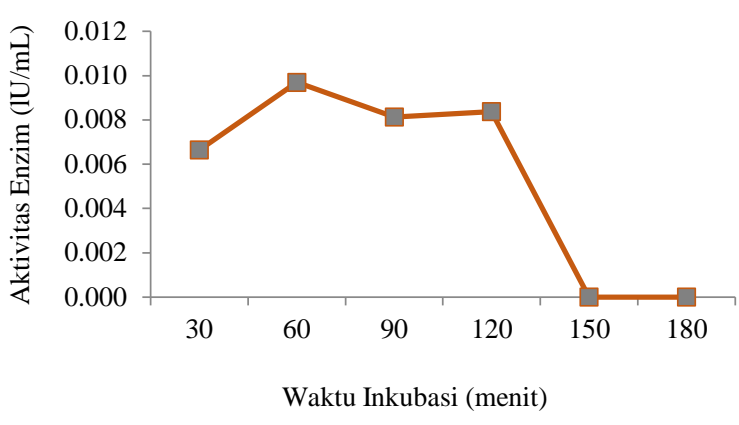

Gambar 2. Aktivitas enzimk-karagenase selama waktu inkubasi

\section{Kadar Gula Reduksi selama Hidrolisis oleh Enzim $\boldsymbol{k}$-Karagenase}

Enzim $k$-karagenase diperoleh dengan cara mencampurkan media produksi karagenase dengan media starter isolat IH22 dan diinkubasi selama 12 jam. Enzim ekstrak kasar yang dihasilkan disentrifugasi untuk memisahkan supernatan dan endapannya (crude) yang kemudian dipekatkan dengan metode pengendapan aseton $80 \%$ (Meliawati, 2015). Perlakuan waktu hidrolisis yang diberikan dimulai dari 0 hingga 180 menit dengan rentang waktu setengah jam. Tahapan ini bertujuan untuk mendapatkan waktu hidrolisis karagenan dalam menghasilkan gula reduksi yang tertinggi oleh enzim $k$-karagenase seperti yang disajikan pada Gambar 3.

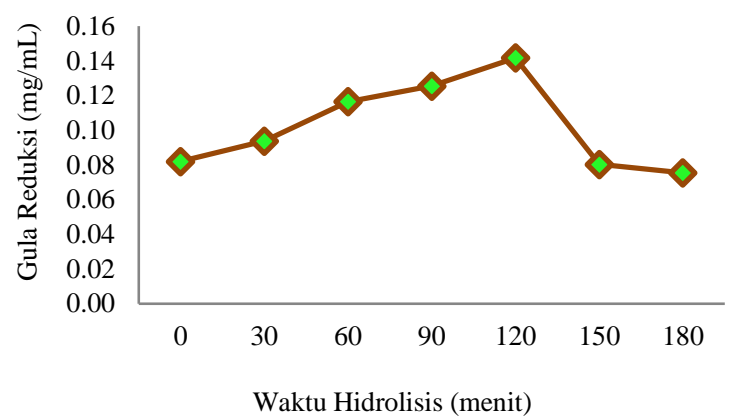

Gambar 3. Gula reduksi k-karagenase selama proses hidrolisis

Gambar 3 menjelaskan bahwa gula reduksi yang dihasilkan dari menit pertama hingga menit ke120 mengalami peningkatan, kemudian pada menit ke-150 menurun hingga menit ke-180. Enzim karagenase menghasilkan gula reduksi yang tinggi pada saat mencapai waktu hidrolisis 2 jam (120 menit). Dimana selain suhu, waktu inkubasi merupakan salah satu faktor yang dapat mempengaruhi besarnya gula reduksi yang dihasilkan. Semakin lama waktu hidrolisis maka akan semakin tinggi kadar gula reduksi yang dihasilkan. Namun jika waktu hidrolisis yang terlalu lama maka akan mengakibatkan gula reduksi (galaktosa) terdegradasi, sehingga menyebabkan konsentrasi gula reduksi menurun dalam proses hidrolisis (Idral et al., 2012). Waktu 2 jam ini selanjutnya digunakan untuk menghidrolisis substrat E.cottonii pada proses hidrolisis oleh enzim $k$ karagenase.

Hidrolisis E.cottoniidengan Enzim $\boldsymbol{k}$-Karagenase Konsentrasi Gula Reduksi dan Total Sebelum Penambahan Enzim

Total gula merupakan campuran gula reduksi dan non reduksi yang merupakan hasil hidrolisis pati. Gula pereduksi merupakan golongan gula (karbohidrat) yang dapat mereduksi senyawasenyawa penerima elektron, contohnya adalah glukosa dan fruktosa. Ujung dari suatu gula pereduksi adalah ujung yang mengandung gugus aldehid atau keton bebas. Semua monosakarida (glukosa, fruktosa, galaktosa) dan disakarida (laktosa, maltosa) kecuali sukrosa dan pati (polisakarida), termasuk sebagai gula pereduksi. (Poedjiadi, 2006).

Karagenan merupakan polisakarida yang linier atau lurus, dan merupakan molekul galaktan dengan unit-unit utamanya adalah galaktosa dari hasil ekstraksi rumput laut. Sebagian besar karagenan mengandung natrium, magnesium, dan kalsium yang dapat terikat pada gugus ester sulfat dari galaktosa dan kopolimer 3,6-anhydro-galaktosa. Tingginya kandungan karagenan pada rumput laut akan memberikan pengaruh terhadap konsentrasi gula reduksi yang dihasilkan. Semakin banyak karagenan/oligosakarida yang terhidrolisis semakin banyak gula reduksi yang terbentuk (Winarno, 2004). Gambar 4 menunjukkan histogram persentase gula reduksi dan total gula yang dihasilkan setelah hidrolisis menggunakan asam pada konsentrasi substrat E.cottonii.

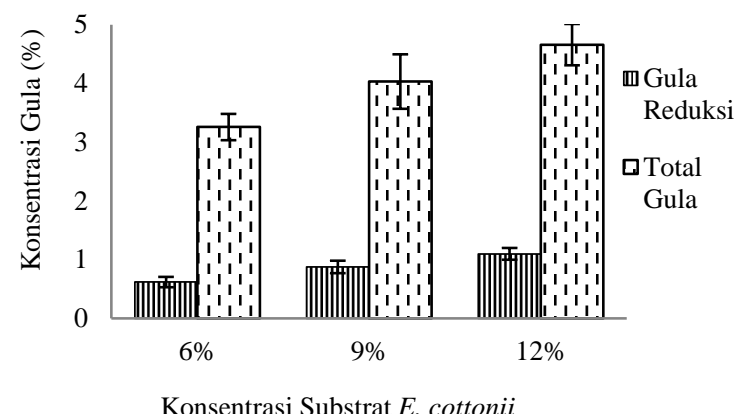

Gambar 4. Pengaruh penambahahan asam terhadap konsentrasi gula reduksi dan total gula yang dihasilkan

Pada Gambar 4 terlihat bahwa semakin tinggi konsentrasi substrat maka semakin besarkadar gula reduksi dan total gula yang dihasilkan. Substrat $12 \%$ merupakan substrat yang paling tinggi dalam menghasilkan gula reduksi dan total gula selama proses hidrolisis menggunakan asam. Hal ini dikarenakan semakin tinggi konsentrasi substrat 
E.cottonii maka semakin banyak pati (polisakarida) yang tersedia untuk hidrolisis oleh asam.

Salah satu yang mejadi faktor utama yang berpengaruh terhadap hasil yang diperoleh dan kecepatan selama proses hidrolisis adalah susbtrat. Semakin tinggi konsentrasi substrat akan menjadi penghambat selama proses hidrolisis karena dapat memperlambat proses. Hal inilah yang menyebabkan kecilnya kandungan gula reduksi dan total gula pada substrat $12 \%$. Berdasarkan rasio antara konsentrasi gula reduksi atau total gula terhadap konsentrasi substrat E.cottonii, konsentrasi gula reduksi yang terkandung setelah dihidrolisis sebelum ditambahkan enzim sebesar 9-10\% dan total gulanya sekitar 40$45 \%$.

\section{Konsentrasi Gula Reduksi dan Total Gula Setelah Hidrolisis Enzimatik}

Proses hidrolisis enzim merupakan proses penguraian suatu polimer yang kompleks menjadi monomer penyusunnya dengan menggunakan enzim. Enzimk-karagenase dalam proses hidrolisis berperan untuk memecah molekul karagenan sehingga menghasilkan neokarrabiosa dan diubah menjadi galaktosa. Kadar gula reduksi dan total gula setelah hidrolisis menggunakan enzim $k$-karagenase pada berbagai konsentrasi substrat E.cottonii disajikan pada Gambar 5.

Pada Gambar 5 terlihat bahwa semakin tinggi konsentrasi substrat dan enzim, gula reduksi dan total gula yang dihasilkan semakin meningkat pula. Dimana selain konsentrasi substrat, enzim $k$ karagenase memberikan pengaruh terhadap konsentrasi gula yang dihasilkan. Hal ini dikarenakan semakin tinggi konsentrasi enzim maka substrat yang berikatan dengan lokasi aktif enzim akan semakin banyak sehingga jumlah produk yang dihasilkan akan semakin banyak (Mauliana, 2015). Substrat $12 \%$ merupakan susbtrat yang memiliki kadar gula reduksi dan total gula yang tertinggi yaitu sebesar 1,94-3,21\% dan 4,26-9,89\%.
Sama halnya pada hidrolisat setelah diberi perlakuan awal asam, besarnya konsentrasi substrat juga dapat mempengaruhi kecepatan hidrolisis enzimatis. Terjadinya penghambatan selama proses hidrolisis selain karena konsentrasi substrat yang tinggi juga dipengaruhi oleh banyaknya enzim yang diberikan. Banyaknya konsentrasi enzim sangat berpengaruh terhadap kecepatan selama proses hidrolisis. Hal ini dapat dilihat dari hasil rasio antara kadar gula reduksi atau total gula terhadap substrat dengan atau tanpa perlakuan enzim. Dimana semakin tinggi konsentrasi substrat semakin kecil kandungan gula reduksi dan total gula yang dihasilkan akan tetapi semakin tinggi konsentrasi enzim yang ditambahkan pada masing-masing substrat semakin tinggi kandungan gula reduksi dan total gula setelah hidrolisis enzimatis. Adapun kandungan gula reduksi yang dihasilkan berkisar antara $16-38 \%$ dengan total gula sebesar $36-90 \%$.

\section{Fermentasi}

Konsentrasi Gula Reduksi dan Total Gula setelah Fermentasi

Pada tahap fermentasi, substrat E.cottonii mengubah menjadi gula sederhana salah satunya adalah galaktosa. Produksi etanol dari substrat gula oleh khamir S.cerevisiae merupakan proses fermentasi dengan kinetika sangat sederhana. Disebut sederhana karena hanya melibatkan satu fasa pertumbuhan dan produksi, pada fase tersebut galaktosa diubah secara simultan menjadi biomassa, etanol dan $\mathrm{CO}_{2}$. Terdapat dua parameter yang dapat mengendalikan pertumbuhan dan metabolisme khamir dalam keadaan anaerobik, yaitu konsentrasi gula dan etanol. Pada Gambar 6 dapat dilihat bahwa konsentrasi gula reduksi dan total gula yang dihasilkan setelah fermentasi mengalami penurunan saat setelah dihidrolisis menggunakan enzim $k$ karagenase, hal ini dikarenakan S.cerevisiae mengkonsumsi gula reduksi selama proses fermentasi untuk proses metabolismenya.

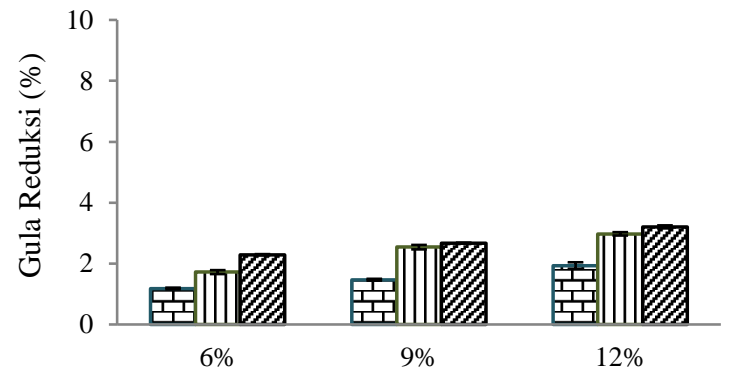

Konsentrasi substrat E. cottonii

(a)

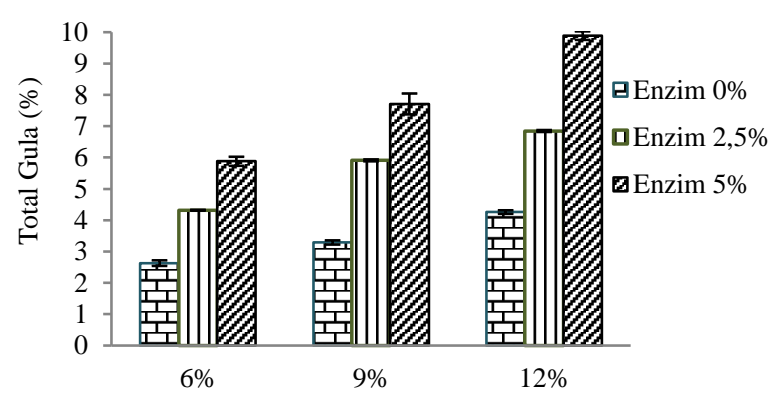

Konsentrasi Substrat E. cottonii

(b)

Gambar 5. Konsentrasi (a) gula reduksi dan (b) total gula setelah hidrolisis enzimatik 
Pada Gambar 6 dapat dilihat bahwa substrat $12 \%$ masih menghasilkan kadar gula reduksi dan total gula yang tinggi. Besarnya kadar gula reduksi dan total gula yang dihasilkan setelah fermentasi, menunjukkan bahwa sedikitnya gula yang dikonsumsi oleh S.cerevisiae selama proses fermentasi. Menurut Osho (2005), khamir memiliki batas toleransi terhadap jumlah gula dalam hidrolisat (substrat). Adapun gula optimum bagi S.cerevisiae adalah sekitar $15-18 \%$.

\section{Konsumsi Gula Reduksi dan Total Gula Selama Fermentasi}

Besarnya konsentrasi gula reduksi dan total gula sebelum dan setelah fermentasi dapat digunakan untuk menentukan konsumsi gula reduksi dan total gula selama proses fermentasi. Adanya perbedaan jumlah gula yang dikonsumsi berhubungan dengan pembentukan etanol, karena gula reduksi yang terukur sebagai galaktosa dapat dimanfaatkan oleh S.cerevisiae dalam proses metabolisme dalam menghasilkan etanol. Gambar 7 adalah histogram konsumsi gula reduksi dan total gula yang dihasilkan selama proses fermentasi.

Berdasarkan gambar diatas menjelaskan bahwa substrat 9\% menghasilkankonsumsi gula reduksi dan total gula yang paling tinggi dibandingkan substrat $6 \%$ dan $12 \%$. Karena selama fermentasi, pada konsentrasi substrat 9\% khamir dapat bekerja secara maksimal dalam mengkonsumsi gula reduksi dengan sangat baik selama fermentasi yaitu sebesar 1,03\%-1,49\%, dan kadar total gula yang dihasilkan sebesar 1,56\%-2,75\%. Pada substrat $12 \%$ konsentrasi gula reduksi yang dikonsumsi masih sangat kecil, dimana secara kinetik glukosa memiliki peran ganda dimana substrat dengan konsentrasi gula yang rendah yaitu kurang dari $1 \mathrm{~g} / \mathrm{L}$ merupakan substrat pembatas, sedangkan konsentrasi gula yang tinggi dimana lebih dari 300 g/L akan menjadi penghambat (Mangunwidjaja, 1994). Hal inilah yang menyebabkan rendahnya konsumsi gula reduksi dan total gula pada substrat $12 \%$.

Berdasarkan nilai kadar gula reduksi yang diperoleh, efisiensi penggunaan substrat dapat dihitung dengan membandingkan persentase total gula reduksi yang dikonsumsi selama fermentasi dengan jumlah gula reduksi awal (sebelum fermentasi). Gambar 8 merupakan histogram nilai efisiensi penggunaan subsrat.

Nilai efisiensi penggunaan substrat berbanding lurus terhadap konsumsi gula reduksi selama fermentasi. Pada Gambar 7, terlihat bahwa substrat 9\% memiliki nilai efisiensi substrat yang paling tinggi dengan atau tanpa perlakuan enzim yaitu sebesar 69,87-55,78\%. Menurut Nababan (2013), semakin tinggi efisiensi penggunaan substrat yang dihasilkan, maka degradasi substrat yang terjadi selama proses hidrolisis akan semakin baik.

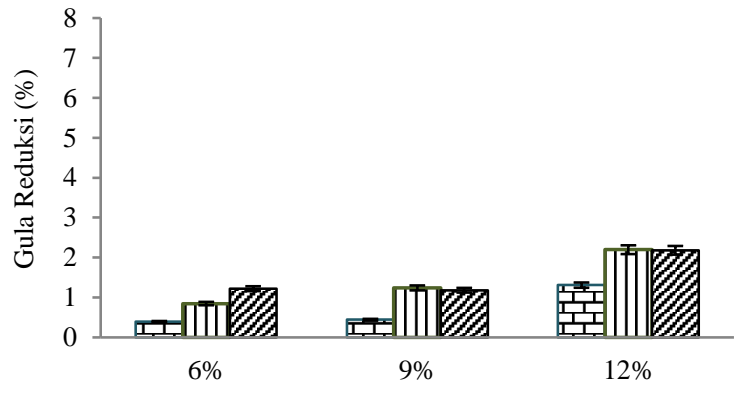

Konsentrasi Substrat E. cottonii

(a)

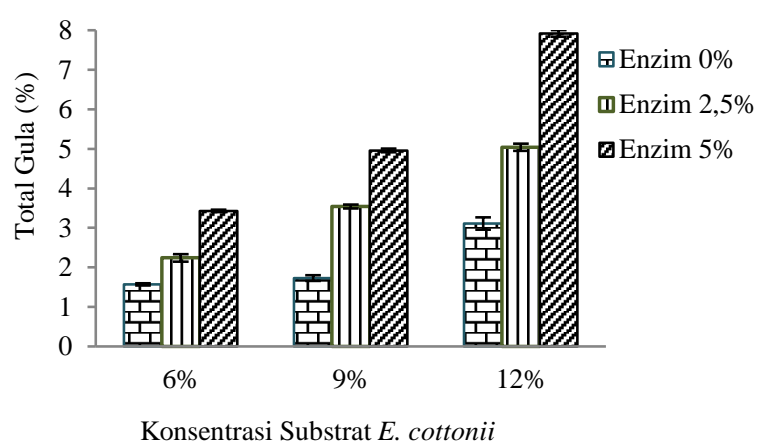

(b)

Gambar 6. Konsentrasi (a) gula reduksi dan (b) total gula setelah fementasi

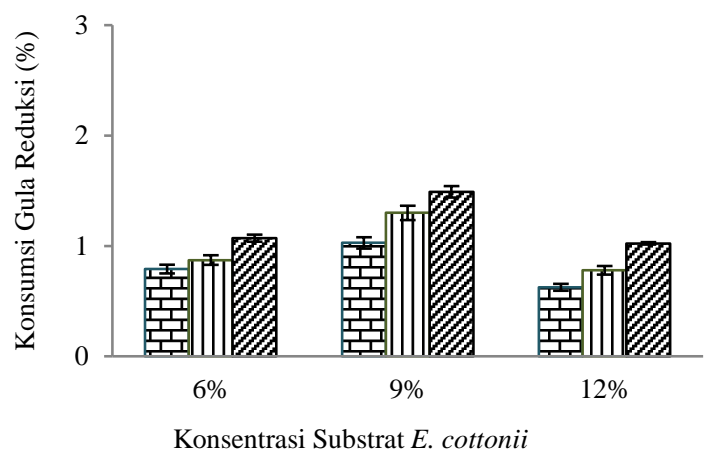

(a)

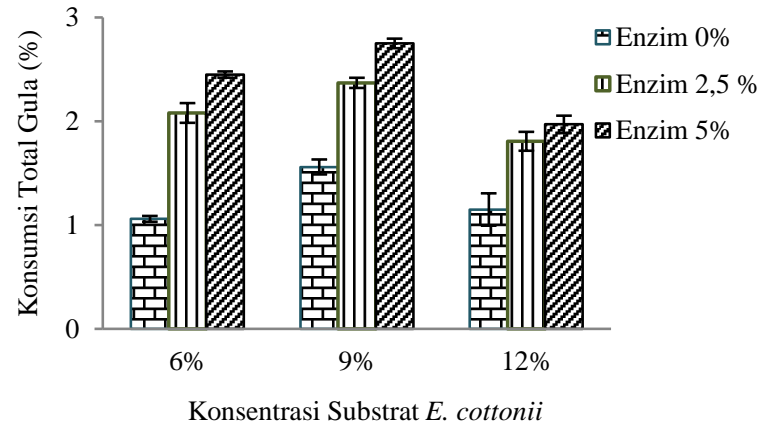

(b)

Gambar7. Konsumsi (a) gula reduksi dan (b) total gula selama fermentasi 


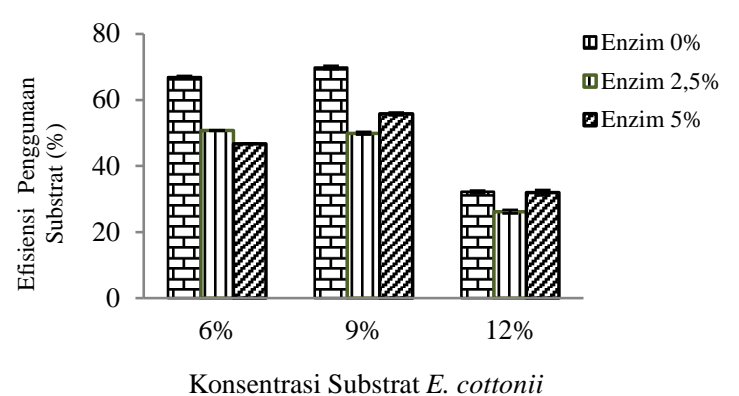

Gambar 8. Efisiensi penggunaan substrat

Efisiensi penggunaan substrat menunjukkan seberapa banyak gula yang dimanfaatkan oleh khamir (S.cereviseae) untuk diubah menjadi etanol (produk utama), asam organik (produk samping) dan energi yang digunakan untuk pertumbuhan khamir.

\section{Kadar Etanol pada Hidrolisat E.cottonii}

Produksi bioetanol merupakan parameter yang dapat menunjukkan keberhasilan dari proses fermentasi alkohol. Selain mikroba, nutrien (urea dan NPK) yang terlibat dalam proses fermentasi, besarnya konsumsi gula reduksi selama proses fermentasi dapat memberikan pengaruh terhadap kadar etanol yang dihasilkan. Semakin banyak gula yang dikonsumsi maka semakin tinggi kadar etanolnya. Hal ini terlihat pada Gambar 8 bahwa substrat 9\% menghasilkan kadar etanol tertinggi sebesar $0,53 \%$ untuk enzim $2,5 \%$ dan $1,24 \%$ pada konsentrasi enzim 5\%. Kadar etanol yang dihasilkan oleh hidrolisis enzim $k$-karagenase masih tergolong rendah, hal ini dikarenakan mikororganisme yang digunakan tidak sesuai dan juga selama proses fermentasi khamir lebih membutuhkan glukosa sebagai sumber energi dibandingkan galaktosa yang banyak dihasilkan oleh hidrolisat E.cottonii.

Berdasarkan penelitian Radesiyani (2013) menyatakan bahwa semua galur khamir mampu mengubah glukosa menjadi bioetanol, namun hanya dua galur khamir yakni P.tannophilus IPBCC y 11.1149 dan S.cerevisiae IPBCC y 03.545 yang dapat menggunakan galaktosa dan hidrolisat rumput laut E.cottonii sebagai media untuk fermentasi. Namun, ketika kedua galur tersebut diuji kemampuan produksi bioetanolnya dari hidrolisat rumput laut E.cottonii, khamir P.tannophilus menunjukkan kemampuan produksi yang lebih baik dengan kadar etanol yang dihasilkan sebesar 0,50$1,18 \%$ sedangkan S.cerevisiae sebesar 0,05-0,58\%. Hal ini menunjukkan P.tannophilus memiliki kemampuan untuk menggunakan galaktosa lebih baik daripada S.cerevisiae. Khamir P.tannophilus diduga lebih toleran terhadap inhibitor dalam hidrolisat E.cottonii dibandingkan dengan S.cerevisiae. Khamir yang toleran terhadap HMF dan furfural akan mengkonversi HMF dan furfural menjadi alkohol (Maharani, 2011).

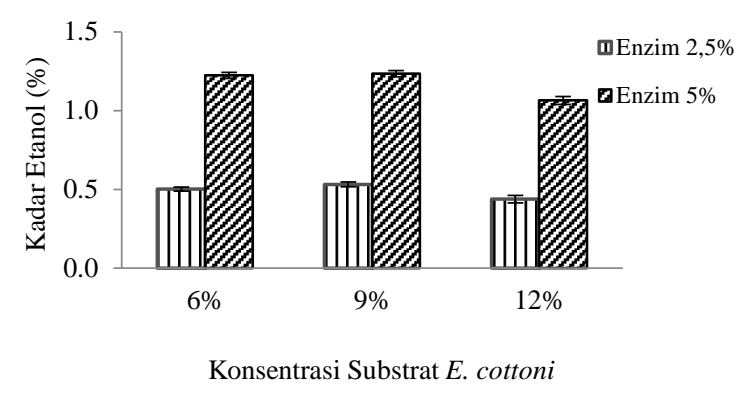

Gambar 9. Kadar etanol pada hidrolisat

Pada Gambar 9 dapat dilihat bahwa adanya perlakuan enzim pada masing-masing substrat dapat meningkatkan kadar etanol. Semakin banyak enzim yang digunakan maka akan semakin tinggi kadar etanol yang dihasilkan. Menurut Nababan (2013), konsentrasi enzim dapat mempengaruhi hasil etanol yang optimal, dimana jumlah etanol optimal yang dihasilkan bergantung pada konsentrasi gula (substrat) yang akan diubah oleh enzim. Sehingga semakin banyak enzim yang ditambahkan maka semakin cepat reaksi kimia pada substrat dalam menghasilkan gula. Akan tetapi konsentrasi gula yang diperlukan untuk fermentasi adalah 10 sampai 18\%. Apabila konsentrasi gula terlalu tinggi maka proses fermentasi akan berjalan lambat.

Sedangkan substrat tanpa penambahan enzim, tidak menghasilkan etanol sama sekali. Hal ini dikarenakan gula yang dihasilkan oleh substrat E.cottonii lebih banyak mengandung galaktosa dibandingkan glukosa dan khamir yang digunakan memiliki kemampuan yang lemah dalam memfermentasi galaktosa. Rendahnya etanol yang dihasilkan pada hidrolisat E.cottonii mungkin diakibatkan oleh adanya senyawa-senyawa inhibitor yang terbentuk pada hidrolisat. Salah satu senyawa inhibitor yang terdapat pada hidrolisat rumput laut. Menurut Maharani (2011), konsentrasi tinggi dari HMF dan asam levulinat dapat menghambat produktivitas fermentasi mikroorganisme sehingga menurunkan produksi etanol. S.cerevisiae juga diduga dapat menggunakan gula sebagai sumber energi untuk menghilangkan inhbitor HMF dan AL daripada memproduksi bioetanol. Akan tetapi dengan adanya senyawa-senyawa inhibitor tersebut mengakibatkan khamir lebih mengutamakan untuk mengurangi senyawa-senyawa inhibitor terlebih dahulu daripada mengkonversi substrat menjadi etanol.

Berdasarkan besarnya konsumsi gula reduksi yang dihasilkan selama fermentasi, dapat disimpulkan bahwa konsentrasi substrat $9 \%$ dengan penambahan enzim 5\% merupakan kombinasi perlakuan yang terbaik dalam menghasilkan etanol yang tertinggi. Pada penelitian ini selain untuk mengetahui kadar etanol pada masing-masing substrat E.cottonii. Perbandingan nilai efisiensi fermentasi dan jumlah $\mathrm{Y}_{\mathrm{p} / \mathrm{s}}$ dapat dilihat pada Tabel 1. 
Tabel 1. Perbandingan nilai efisiensi fermentasi dan $\mathrm{Y}_{\mathrm{p} / \mathrm{s}}$ pada hidrolisat E.cottonii

\begin{tabular}{lccc}
\hline \multicolumn{1}{c}{ Perlakuan } & Efisiensi fermentasi $(\%)$ & $\begin{array}{c}\text { Y } \mathbf{p} / \mathbf{s} \text { (g etanol/ } \\
\text { g bhn kering) }\end{array}$ & $\begin{array}{c}\mathbf{Y}_{\mathbf{p} / \mathbf{s}}(\mathbf{e t a n o l} / \boldsymbol{\Delta} \\
\text { g.reduksi) }\end{array}$ \\
\hline Substrat 6\% & - & - & - \\
Enzim 0\% & 44,39 & 0,07 & 0,57 \\
Enzim 2.5\% & 81,70 & 0,16 & 1,14 \\
Enzim 5\% & - & & - \\
Substrat 9\% & 31,44 & - & 0,41 \\
Enzim 0\% & 70,44 & 0,05 & 0,83 \\
Enzim 2.5\% & - & 0,11 & - \\
Enzim 5\% & 22,35 & & 0,56 \\
Substrat 12\% & 50,41 & - & 1,05 \\
Enzim 0\% & & 0,03 & \\
Enzim 2.5\% & & 0,07 & \\
Enzim 5\% & & & \\
\hline
\end{tabular}

Berdasarkan Tabel 1, nilai efisiensi fermentasi pada substrat $6 \%$ memiliki nilai yang paling tinggi dibandingkan dengan substrat 9 dan $12 \%$ yaitu sebesar 44,39 dan $81,70 \%$. Tingginya nilai efisiensi yang dihasilkan menunjukkan bahwa kinerja dari khamir pada konversi gula menjadi etanol sangat baik demikian halnya pada efisiensi penggunaan substrat (Nababan, 2013).

Efisiensi fermentasi merupakan ukuran banyaknya jumlah gram etanol yang terbentuk per $100 \mathrm{~g}$ gula dalam substrat dibandingkan dengan gram etanol yang terbentuk secara teoritis. Efisiensi fermentasi etanol menunjukkan banyaknya mol gula yang diubah menjadi etanol. Besar kecilnya nilai efisiensi sangat bergantung pada konsentrasi substrat dan kadar gula reduksi yang dihasilkan. Semakin banyak konsentrasi substrat yang digunakan akan menghasilkan gula reduksi yang tinggi sehingga berpengaruh terhadap nilai efisiensi fermentasi yang dihasilkan. Selain itu, adanya faktor enzim juga dapat meningkatkan kadar gula reduksi pada substrat E.cottonii. Berdasarkan hasil sidik ragam yang dihitung adanya faktor substrat dan enzim memberikan pengaruh yang berbeda nyata terhadap efisiensi fermentasi yang dihasilkan.

Nilai efisiensi fermentasi yang dihitung pada Tabel 1 merupakan basis perhitungan terhadap glukosa, sedangkan kandungan gula reduksi yang terdapat pada E.cottonii ( $k$-karagenan) sebagian besar adalah galaktosa. Sehingga perlu dilakukan perhitungan terhadap total yield $\left(\mathrm{Y}_{\mathrm{p} / \mathrm{s}}\right)$ etanol per konsentrasi substrat (bahan kering) dan konsumsi gula reduksi yang dihasilkan selama fermentasi. Pada Tabel 2 dapat dilihat bahwa nilai $\mathrm{Y}_{\mathrm{p} / \mathrm{s}}$ dengan produk (etanol) dan substrat (bahan kering dan $\Delta$ gula reduksi), memiliki nilai yang berbeda pada tiap perlakuan. Substrat $6 \%$ merupakan substrat dengan nilai $\mathrm{Y}_{\mathrm{p} / \mathrm{s}}$ yang tertinggi, yaitu sebesar 0,07 dan 0,16 pada $\mathrm{Y}_{\mathrm{p} / \mathrm{s}}$ (gram etanol/gram bahan kering). Sedangkan nilai $\mathrm{Y}_{\mathrm{p} / \mathrm{s}}$ (etanol/ $\Delta$ gula reduksi) sebesar 0,57 dan 1,14. Berdasarkan perbandingan tersebut dapat disimpulkan bahwa semakin tinggi konsentrasi substrat serta besarnya konsumsi gula reduksi maka nilai $\mathrm{Yp} / \mathrm{s}$ yang dihasilkansemakin kecil.

\section{KESIMPULAN DAN SARAN}

\section{Kesimpulan}

Berdasarkan penelitian yang telah dilakukan dapat disimpulkan bahwa aktivitas enzim berjalan dengan baik pada waktu inkubasi $30-60$ menit, sedangkan akumulasi gula reduksi tertinggi diperoleh pada waktu hidrolisis selama 120 menit. Selama proses hidrolisis dengan perlakuan konsentrasi substrat dan enzim, substrat $12 \%$ menghasilkan gula reduksi dan total gula tertinggi yaitu sebesar $3,21 \%$ dan $9,89 \%$. Selama proses fermentasi, substrat $9 \%$ pada perlakuan enzim $5 \%$,yang memiliki kadar gula reduksi dan total gula sebesar $1,49 \%$ dan $2,75 \%$ merupakan kombinasi terbaik dalam menghasilkan etanol yang tertinggi yaitu sebesar $1,23 \%$.

\section{Saran}

Pada peneliti selanjutnya disarankan untuk menggunakan khamir teradaptasi yang dapat menggunakan galaktosa dan hidrolisat rumput laut E.cottonii sebagai media fermentasi salah satunya adalah P. Tannophilus. Kemudian perlu dilakukan penelitian lanjut terhadap waktu inkubasi selama proses fermentasi sehingga didapat waktu inkubasi yang tepat menggunakan enzim $k$-karagenase dalam menghasilkan etanol yang optimal.

\section{DAFTAR PUSTAKA}

Antonopoulos A, Patrick F, William H dan Michel L. 2004. Isolation of $k$-carrageenan oligosaccharides using ion-pair liquid chromatography characterisation by electrospray ionisation mass spectrometry in positive-ion mode. Carbohydrate Research. 339: 1301-1309.

Banati F. 2008. Pengaruh penambahan enzim $\alpha$ Amilase pada fermentasi karbohidrat 
ekstrak Ulvafasciata dari Bale Kamban, Malang menggunakan ragi roti fermipan [Skripsi]. Surabaya: Institut Teknologi Surabaya.

Bawa BAGI, Putra BAA, dan Laila RI. 2007. Penentuan $\mathrm{pH}$ optimum isolasi karagenan dari rumput laut jenis Eucheuma Cottonii. Kimia 1: 15-20.

Campo VL, Daniel FK, Dílson Braz da Silva Jr, Ivone Carvalho. 2009. Carrageenans: Biological properties, chemical modifications and structural analysis - A review. Carbohydr Polym.167-180.

Doty MS. 1987. The Production and Uses of Eucheuma. Didalam: Doty MS, Caddy Jf, Santelices B (editors). Studies of Seven Commercial Seaweeds Resources. FAO Fish. Tech. Paper No. 281 Rome. P 123161.

Gomez KA dan Gomez AA. 1995. Prosedur Statistik untuk Penelitian Pertanian [Edisi kedua]. Terjemahan Endang Sjamsuddin dan Justika S. Baharsjah. Jakarta: Universitas Indonesia (UI-Press), hlm: 1316.

Idral DD, Salim M, dan Mardiah E. 2012. Pembuatan bioetanol dari ampas sagu dengan proses hidrolisis asam menggunakan S. cerevisiae. J Kimia. 1(1): 34-39.

Istini S, Zatnika A, dan Suhaimi. 1986. Manfaat dan Pengolahan Rumput laut. Jakarta: Badan Pengkajian dan Penerapan Teknologi. hlm: 128-135.

Khambhaty Y, Mody K, dan Jha B. 2007. Purification and characterization of $k$ carrageenase from a Novel $r$ protobacterium, Pseudomonas elongata (MTCC 5261) syn. Microbulbifer elongatus com. Nov. Biotechno Bioproc Eng. 12: 668-675.

Knutsen SH dan Hans G. 1992. Analysis of carrageenans by enzymic degradation, gel filtration and ${ }^{1} \mathrm{H}$ NMR spectroscopy. Carbohydrate Polym. 19: 199-210.

Maharani DM. 2011. Adaptasi Saccharomyces cerevisiae terhadap hidrolisat asam ubi kayu untuk produksi etanol [Tesis]. Bogor: Institut Pertanian Bogor.

Mangunwidjaja D dan Suryani A. 1994. Teknologi Bioproses. Jakarta: Penebar Swadaya.

Mauliana RS, Sutikno, dan Marniza. 2015. Effect of Seaweed (Eucheuma cottonii) Extraction and Hydrolysis On Reducing Sugar For Bioethanol Production. Naskah Seminar Nasional Sains \& Teknologi VI Lembaga Penelitian dan Pengabdian Universitas Lampung. Lampung. hlm: 447-458.
Meinita MDN, Ji-Young K, Gwi-Taek J, Hyun MK, Sung MP, Yong-Ki H. 2012. Bioethanol production from the acid hydrolysate of the carrageenophyte Kappaphycus alvarezii (E. cottonii). J Appl Phycol. 24: 857-862.

Meliawati T. 2015. Karakterisasi enzim karagenase dari isolat mikroba laut untuk hidrolisis Eucheuma cottonii. [Skripsi]. Bogor: Institut Pertanian Bogor.

Michel G, Laurent C, Emile D, Tristan B, Bernard H, Bernard K dan Otto D. 2001. The $k$ carrageenase of $P$. carrageenovora features a tunnel-shaped active site: $a$ novel insight in the evolution of clan- $B$ Glycoside Hydrolases. Structure. 9: 513525.

Miller GL. 1959. Use of dinitrosaiicyiic acid reagent for determination of reducing sugar. J. Analytical Chemistry. 31(3): 426428, ISSN 0003-2700.

Nababan D. 2013. Hidrolisis enzimatik untuk meningkatkan produksi bioetanol dari makroalga (E. cottonii) [Skripsi]. Bogor: Institut Pertanian Bogor.

Osho A. 2005. Ethanol and sugar tolerance of wine yeasts isolated from fermenting cashew apple juice. Afri J Biotechnol. 4: 660-662.

Poedjiadi A. 2006. Dasar - Dasar Biokimia. Edisi Revisi. Jakarta: Universitas Indonesia Press.

Rahmadini I. 2012. Pemurnian dan karakterisasi enzim selulose dari bakteri yang diisolasi dari limbah rumput laut. [Tesis]. Bogor: Institut Pertanian Bogor.

Radesiyani I. 2013. Potensi khamir dalam fermentasi hidrolisat rumput laut(Kappaphycus alvarezii) menjadi bioetanol. [Skripsi]. Bogor: Institut Pertanian Bogor.

Riyanti EI. 2008. Biomassa Sebagai Bahan Baku Bioetanol. Bogor. Balai Besar Penelitian dan Pengembangan Bioteknologi dan Sumberdaya Genetika Pertanian - IPB.

Setyaningsih D, Windarwati S, Khayati I, Muna N, Hernowo P. 2012. Acid hydrolysis technique and yeast adaptation to increase red macroalgae bioethanol production. Int J Environ Bioen. 3(2): 98-110.

Sutarto I. 2009. Challenges of Biofuel Industry in Indonesian. Naskah Seminar Nasional pada Dies Natalis Fakultas Teknologi Pertanian-IPB. Bogor. 16 Oktober 2009.

Taherzadeh MJ dan Karimi K. 2007. Acid-based hydrolysis processes for etanol from lignocellulosic material. J Biores. 2: 472499.

Trust N. 2008. Ethanol Fermentation Batch Reactor Design Basic. New Jersey: Team 
Analysts, GB Analysts Reports. Hackensack.

Van de Velde F, Knutsen SH, Usov AI, Romella HS, Cerezo AS. 2002. $1 \mathrm{H}$ and $13 \mathrm{C}$ high resolution NMR spectoscopy of carrageenans: aplication in research and industry. J Trends in Food Sci Technol. 13: 73-92.
Winarno FG. 2004. Kimia Pangan dan Gizi. Gramedia: Jakarta.

Yanagisawa M, Kanami N, Osamu A, Kiyohiko N. 2011. Production of high concentrations of bioethanol from seaweeds that contain easily hydrolysable polysaccharides. Proc Biochem. 46: 2111-2116. 